\section{OPEN ACCESS}

Edited and reviewed by:

Bin Yu,

Government of Canada, Canada

*Correspondence:

Huixin $L$

lihuixin@nuist.edu.cn

Bo Sun

sunb@nuist.edu.cn

Specialty section:

This article was submitted to

Atmospheric Science,

a section of the journal

Frontiers in Earth Science

Received: 09 October 2020 Accepted: 28 October 2020

Published: 14 January 2021

Citation:

Wang Y, Li H, Sun B, Chen H, Li H and Luo Y (2021) Corrigendum: Drought Impacts on Hydropower Capacity

Over the Yangtze River Basin and Their

Future Projections Under $1.5 / 2^{\circ} \mathrm{C}$

Warming Scenarios.

Front. Earth Sci. 8:615438.

\title{
Corrigendum: Drought Impacts on Hydropower Capacity Over the Yangtze River Basin and Their Future Projections Under $1.5 / 2^{\circ} \mathrm{C}$ Warming Scenarios
}

\begin{abstract}
Yu Wang ${ }^{1,3}$, Huixin $\mathrm{Li}^{1,2 *}$, Bo Sun ${ }^{1,2 *}$, Huopo Chen ${ }^{2}$, Hua $\mathrm{Li}^{1,2}$ and Yinxue Luo ${ }^{4}$
${ }^{1}$ Collaborative Innovation Center on Forecast and Evaluation of Meteorological Disasters/Key Laboratory of Meteorological Disasters, Ministry of Education/Joint International Research Laboratory of Climate and Environment Change, Nanjing University of Information Science and Technology, Nanjing, China, ${ }^{2}$ College of Atmospheric Science, Nanjing University of Information Science and Technology, Naniing, China, ${ }^{3}$ Nansen Zhu International Research Centre, Institute of Atmospheric Physics, Chinese Academy of Sciences, Beijing, China, ${ }^{4}$ School of Applied Meteorology, Nanjing University of Information Science and Technology, Nanjing, China
\end{abstract}

Keywords: drought, hydropower capacity, Yangtze River Basin, 1.5/2 ${ }^{\circ} \mathrm{C}$ warming scenarios, interannual increment

\section{A Corrigendum on}

Drought Impacts on Hydropower Capacity Over the Yangtze River Basin and Their Future Projections Under $1.5 / 2{ }^{\circ} \mathrm{C}$ Warming Scenarios

by Wang, Y., Li, H., Sun, B., Chen, H., Li, H., and Luo, Y. (2020). Front. Earth Sci. 8:578132. doi: 10. 3389/feart.2020.578132

In the original article, there is a mistake in Figure $\mathbf{1 0}$ as published. The figure was an old version mistakenly submitted by the authors. The corrected figure appears below.

The authors apologize for this error and state that this does not change the scientific conclusions of the article in any way. The original article has been updated.

Copyright (C) 2021 Wang, Li, Sun, Chen, Li and Luo. This is an open-access article distributed under the terms of the Creative Commons Attribution License (CC BY). The use, distribution or reproduction in other forums is permitted, provided the original author(s) and the copyright owner(s) are credited and that the original publication in this journal is cited, in accordance with accepted academic practice. No use, distribution or reproduction is permitted which does not comply with these terms. 


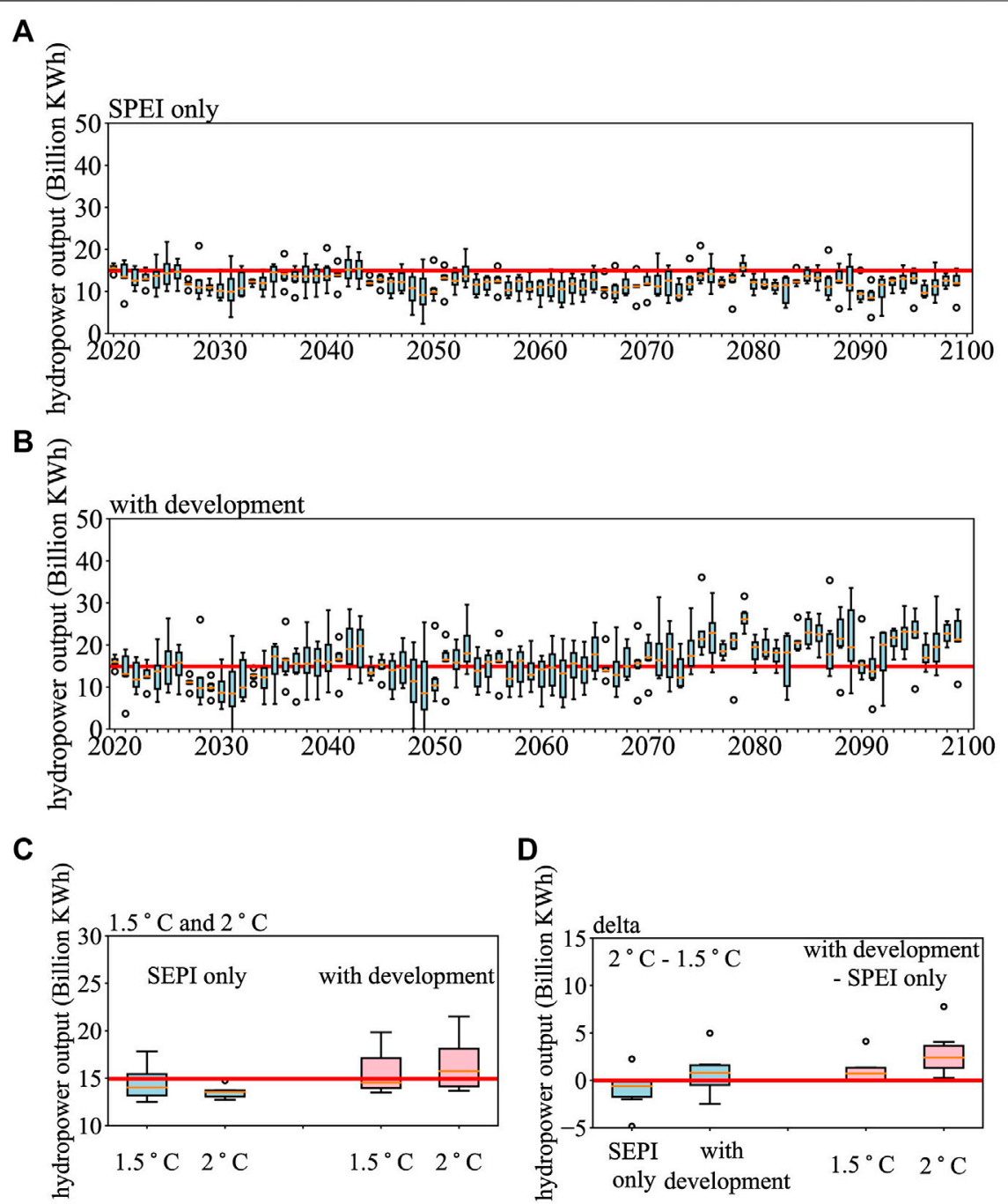

FIGURE 10 | Projections of hydropower capacity in Zhejiang Province during 2020-2100 under RCP4.5 when (A) considering only the meteorological condition and (B) considering the joint effects of the meteorological condition and the development of the hydropower station. (C) Projections of hydropower capacity in Zhejiang Province under the 1.5 and $2{ }^{\circ} \mathrm{C}$ warming target when only the meteorological conditions are considered (blue) and considering the joint effects of the meteorological condition and the development of the hydropower station (pink). (D) Differences between the 2 and $1.5{ }^{\circ} \mathrm{C}$ warming target (blue) and the effects of considering the development of hydropower stations (pink). The red lines indicate the historical mean (1999-2018) of hydropower capacity in Zhejiang Province in (A-C) and indicate the zero lines in (D). Open circles indicate abnormal data, color rectangles denote the spread of the 25th and the 75th quartiles, and the short orange line represents the median condition. 